\title{
Metabolic Signaling Cascades Prompted by Glutaminolysis in Cancer
}

\author{
Raj Shah ${ }^{1,2}$ (D) and Suzie Chen ${ }^{1,2,3, *}$ \\ 1 Susan Lehman Cullman Laboratory for Cancer Research, Ernest Mario School of Pharmacy, \\ Department of Chemical Biology, Rutgers University, Piscataway, NJ 08901, USA; \\ rajs@scarletmail.rutgers.edu \\ 2 Joint Graduate Program in Toxicology, Rutgers University, Piscataway, NJ 08901, USA \\ 3 Rutgers Cancer Institute of New Jersey, New Brunswick, NJ 08901, USA \\ * Correspondence: suziec@pharmacy.rutgers.edu
}

Received: 10 July 2020; Accepted: 9 September 2020; Published: 14 September 2020

Simple Summary: Within the last few years, accumulating evidences suggest the involvement of altered metabolisms in human diseases including cancer. Metabolism is defined as the sum of biochemical processes in living organisms that produce and consume energy. Tumor growth requires restructuring of cellular metabolism to meet the increasing demand for building blocks to support the ever-increasing cancer cell numbers. The principle of perturbed metabolism in tumors is known for 50-60 years, it regains greater appreciation within the last few years with the realization that there is interdependency between metabolism and all aspects of cellular function including regulation and control of cell growth. Tumor cells do not need stimulation signals from the surrounding environment to promote cell proliferation; in some cases, the tumor cells can generate their own growth signals. In order to support the continuous tumor cell growth even under stressful conditions, a change in metabolism is necessary to fulfill the continuous demand for energy and building blocks. A better understanding of the relationship between tumor environment and altered cell metabolisms will provide valuable insights to design innovative approaches to limit the supply of energy and macromolecules for the treatment of cancer including melanoma.

\begin{abstract}
Aberrant glutamatergic signaling has been implicated in altered metabolic activity and the demand to synthesize biomass in several types of cancer including melanoma. In the last decade, there has been a significant contribution to our understanding of metabolic pathways. An increasing number of studies are now emphasizing the importance of glutamate functioning as a signaling molecule and a building block for cancer progression. To that end, our group has previously illustrated the role of glutamatergic signaling mediated by metabotropic glutamate receptor 1 (GRM1) in neoplastic transformation of melanocytes in vitro and spontaneous development of metastatic melanoma in vivo. Glutamate, the natural ligand of GRM1, is one of the most abundant amino acids in humans and the predominant excitatory neurotransmitter in the central nervous system. Elevated levels of glutaminolytic mitochondrial tricarboxylic acid (TCA) cycle intermediates, especially glutamate, have been reported in numerous cancer cells. Herein, we highlight and critically review metabolic bottlenecks that are prevalent during tumor evolution along with therapeutic implications of limiting glutamate bioavailability in tumors.
\end{abstract}

Keywords: metabolism; cancer; glutamine; glutamate; glutaminase (GLS); glutaminolysis; CB-839

\section{Introduction}

Hanahan and Weinberg first proposed the six biological hallmarks of cancer in 2000, and four additional new hallmarks as necessary traits during the development and progression of cancer 
were subsequently added in 2011 [1]. These hallmarks are unregulated cell growth, anti-apoptosis signals, induction of angiogenesis, unresponsiveness to growth suppressors, metastatic capabilities, replicative immortality, genomic instability, immune system evasion, tumor-specific inflammatory response, and transformation of cellular metabolism. Cancer cells are constantly adapting to the hosts' defense by manipulating intrinsic and extrinsic biological pathways. Within the last two decades, reprogramming of energy metabolism has emerged as a popular and valuable therapeutic cancer target to study. Cell metabolism, simply defined, is the set of complex biochemical processes occurring in a cell required to sustain life. Due to their utterly plastic nature, cancer cells may utilize a plethora of pathways for energy production [2]. Metabolic pathways are composed of numerous steps that are highly regulated, and it is possible for metabolites formed in one pathway to feed into other biosynthetic pathways. In cancer, these pathways differ depending on the tissue of origin and are often rewired allowing tumor cells to sustain hyper-growth and proliferative states.

\section{Aerobic Glycolysis “Warburg Effect”}

Cancer cells employ a different metabolic strategy than normal cells to satisfy their energy requirements and sustain cellular proliferation. Under aerobic conditions, normal cells acquire their energy primarily from the conversion of glucose to pyruvate by a process known as glycolysis, which occurs in the cytosol. The pyruvate then enters the tricarboxylic acid (TCA) cycle where it converts into carbon dioxide in the mitochondria via oxygen-consuming cellular respiration $[3,4]$. However, under hypoxic conditions where oxygen is not readily available, cells prefer to rely more on anaerobic glycolysis, which converts glucose into lactate instead of pyruvate, resulting in decreased availability of pyruvate for mitochondrial respiration (oxidative phosphorylation). It has been noted, however, that cancer cells often produce large amounts of lactate regardless of the availability of oxygen, and this form of metabolism is referred to as "aerobic glycolysis" or the "Warburg effect" $[3,5,6]$. This phenomenon was first observed in 1924 by the Nobel laureate and German scientist, Otto Warburg. Moreover, a recent review has highlighted the roles of hypoxia inducible factor 1 (HIF-1) and the PI3K/AKT/mTOR pathway in reprogramming metabolism of cancer cells towards preferential utilization of aerobic glycolysis as an energy source [7]. While aerobic glycolysis is considerably less efficient than cellular respiration in terms of adenosine triphosphate (ATP) generation-2 ATP versus 36 ATP, respectively-when the cell microenvironment is nutrient limited, aerobic glycolysis can provide an advantage for tumor-cell growth by generating ATP at a faster rate [8]. It has been suggested, however, that the reason for this 'metabolic switch' is not to increase ATP production, since the amount of ATP in a proliferating cell is not significantly different from a resting cell, but rather to provide the building blocks for macromolecular synthesis $[9,10]$.

\section{Tricarboxylic Acid (TCA) Cycle}

Under aerobic conditions, pyruvate, the end product of glycolysis, enters the mitochondria to be oxidized to acetyl Coenzyme A (CoA), which combines with oxaloacetate to start the TCA cycle and oxidative phosphorylation [2]. One predominant metabolic rewiring activity distressing the TCA cycle is that many cancer cells exhibit remarkable dependence on glutamine and cannot survive with glutamine deprivation [11]. This phenomenon is often referred to as 'glutamine addiction'. Experimental evidence suggests that glutamine is the major respiratory fuel for energy production in tumor cells [12]. Glutamine is the most abundant amino acid in human blood [13,14]. In addition to being a nitrogen donor for protein and nucleotide synthesis, glutamine provides for anaplerosis to refill the mitochondrial carbon pool. During periods of rapid growth, the demand for glutamine surpasses its supply in many cancer cells [15]. It has been demonstrated that tumor cells can utilize glutamine for citrate production through the reversal (reductive carboxylation) of the TCA cycle [16]. First, glutamine is de-aminated to glutamate, via glutaminase (GLS), which is then converted to $\alpha$-ketoglutarate. Next, $\alpha$-ketoglutarate undergoes reductive carboxylation to generate isocitrate by isocitrate dehydrogenase (IDH). At last, isocitrate is catalyzed by aconitase to produce citrate, which is converted to acetyl CoA 
by ATP citrate lyase [17]. Overall, both glutamine and glucose may provide the carbon skeletons and co-factors, such as NADPH and ATP, for cancer growth and survival.

\section{Factors that Can Potentially Affect Metabolic Activity in Cancer Cells}

Earlier, only genomic modifications that result in the activation of oncogenes, loss of tumor suppressors, or mitochondrial DNA mutations were expected to regulate cancer-cell metabolism. Lately, it has been recognized that the metabolic phenotype of cancer cells can also be influenced by several non-genetic factors. As the number of neoplastic cells increases in the tumor, nutrient and oxygen availability gradually begins to decrease. This triggers the formation and growth of new blood vessels that are poorly formed and inefficient [18]. Subsequent changes in the availability of nutrients are known to have a significant impact on actively proliferating carcinomas. Moreover, contrary to the traditional view that cells can take up and utilize nutrients whenever their reserves are depleted, nutrient uptake is strictly regulated by growth factor signaling [19]. In addition to nutrient availability, metabolism could also be modulated by the surrounding tumor microenvironment (TME) of the cancer cell. Hypoxic conditions in the TME could activate a transcriptional program that could theoretically change the metabolic profile of cancer cells $[20,21]$. There have been reports suggesting that the molecular basis for the shift from oxidative to reductive glutamine metabolism in mammalian cells is linked to HIF-1 $\alpha$ activity [22]. An area that has distorted the viewpoints of multiple experts is the questionable contribution of stromal cell-generated metabolites to the tumor and whether these metabolites promote or inhibit tumor advancement. Taken together, these insights shed light on intrinsic and extrinsic factors that disrupt metabolism, all of which can have important implications in cancer development and progression.

\section{Physiological Role of Glutamate in Normal and Cancer Cells}

Glutamate is the most abundant and multifaceted biomolecule that plays a fundamental role in multiple metabolic processes and signaling in human cells. Glutamate, the predominant excitatory neurotransmitter in the central nervous system (CNS), is also involved in several non-neuronal cellular functions through interaction with different receptors [23]. Glutamate has been shown to regulate proliferation, migration, and survival of neuronal precursor cells during development of the brain [24]. Glutathione (GSH), an important scavenger of reactive oxygen species (ROS) found in the cytosol of all human cells, is made up of glutamate, glycine, and cysteine. Tumor cells express elevated levels of antioxidant proteins, such as GSH for detoxification [25], further endorsing the importance of glutamate. Post conversion to $\alpha$-ketoglutarate by glutamate dehydrogenase (GLDH), glutamate-produced from oxidation of glutamine-may enter the TCA cycle to supply intermediates for cell growth [2]. When the supply of glutamine is scarce, glutamate, and ammonia can be condensed in an ATP-dependent manner for de novo glutamine synthesis by glutamine synthetase (GS), otherwise known as the glutamate-ammonia ligase (GLUL) [26]. Most metabolic pathways where the free ammonia is utilized, the efficiency of nitrogen utilization is maximized as the cells prefer to transfer nitrogen from amino acids $[27,28]$. However, the GS catalyzed reaction is special, because it plays an important role in nitrogen metabolism, ammonia detoxification, and cell signaling [29]. Evidence points to the involvement of glutamate in cancer progression and regulation of the TME [30]. Moreover, supplementation of glutamic acid in conditioned media stimulated proliferation in slow-growing melanoma cells [31,32], indicative of a growth advantage. This likely has to be attributed to the fact that abundant glutamate in the TME supports efficient carbon utilization for anabolism and growth [33]. In fact, studies have showed that excessive glutamate concentrations in the TME of glioblastoma patients results in accelerated tumor growth [34] possibly leading to epileptic seizures in those patients [35]. Furthermore, glutamate antagonists have been shown to limit tumor growth, migration, and invasiveness in human tumors, including breast, colon, lung, and astrocytoma, showing their anticancer potentials [36]. Increasing knowledge of glutamate signaling in tumorigenesis may lead us towards finding putative targets against various components of glutamate-mediated signaling. 
Interestingly, one of the most noticeable reprogramming events in cancer-cell metabolisms is the preferential utilization of glutamate for reductive metabolism even under normoxic conditions. Recently, several reports have linked resistance to serine/threonine protein kinase BRAF (BRAF) inhibitors with augmented glutamine dependency [37-39], suggesting that altered glutamate-dependent anabolic pathways may be central to acquiring drug resistance in cancers including melanoma. Additionally, two large omics studies have highlighted the role of glutamate-mediated activation of G-protein coupled receptors (GPCRs) in conferring BRAF inhibitor resistance in melanoma cells [40,41].

\section{Glutaminolysis}

In the late 1950s, it was found that some cancer cells could not survive without the addition of exogenous glutamine in the growth media, suggesting that tumor cells are highly dependent on glutamine for survival and growth [42]. Experimental evidence shows that glutamine is the major respiratory fuel for energy production in tumor cells [43]. The ability of glutamine to satisfy the bioenergetic needs and provide intermediates for macromolecular synthesis required for cell growth is important in tumor-cell metabolism [12]. Thus, the metabolism of glutamine is considered another important hallmark besides the "Warburg effect" in tumor-cell metabolism. In humans, glutamine has the highest concentration in the blood plasma relative to other amino acids, ranging from concentrations of 0.5 to $1 \mathrm{mM}[10,15]$. Due to its extracellular abundance, glutamine is transported into the cell via the SLC1A5 (ASCT2) transporter [44-46]. The internalized glutamine is then oxidized through the loss of its amide group to form glutamate, by a mitochondrial-associated enzyme called glutaminase (GLS) [47,48]. GLS is an amidohydrolase that is often referred to as the "key gatekeeper" of glutamate-driven glutaminolysis [49]. The reverse reaction is catalyzed by another enzyme, glutamine synthetase (GS), which catalyzes the conversion of glutamate back into glutamine, and has been implicated in cancers, such as primary liver cancer and hepatocellular carcinoma [50,51]. Byproducts of the "glutaminase" reaction are used for synthesis of purines, pyrimidines, $\mathrm{NAD}^{+}$cofactors, amino-sugars, glutathione, and non-essential amino acids (NEAA), such as alanine, asparagine, and phosphoserine $[45,46,52]$.

The human genome encodes two distinct isoforms of glutaminases: kidney-type glutaminase (KGA) and liver-type glutaminase (LGA). Different isoforms of each enzyme arise from alternative splicing and surrogate promoter mechanisms [53]. KGA, which has ubiquitous distribution, is encoded by the GLS1 gene on chromosome 2, whereas LGA, mainly expressed in liver tissues, is derived from the GLS2 gene on chromosome 12. KGA exists as two splice variants through alternative splicing: one expressing the full length form of the GLS1 gene, which retains the acronym KGA, and the other is termed as kidney glutaminase isoform C (GAC), which has a 71 residue shorter carboxy-terminus [49]. Numerous evidence implicates that upregulation of KGA, especially GAC (jointly referred to as GLS henceforth), plays a critical role in tumor proliferation throughout various types of cancers, such as glioma, lymphoma, non-small cell lung cancer, prostate cancer, and triple-negative breast cancer [54-57]. Furthermore, downregulation or inhibition of GLS has slowed the proliferation of these tumor cells [57,58]. GLS inhibition has been shown to enhance the effectiveness of chemotherapy [59] and also improve the efficacy of other targeted therapies [60,61], suggesting the critical role of targeting GLS in an attempt to improve overall patient response. Elevated GLS levels are functionally linked to the oncogenic transcription factor, Myc. Myc-induced cell growth [62] has emerged as an important player in numerous cancer types [54]. The vital role of glutamate in cancer-cell proliferation suggests that glutaminolytic enzymes could be attractive targets for therapy. A schematic illustration describing the metabolic fates of glutamate is shown in Figure 1. 


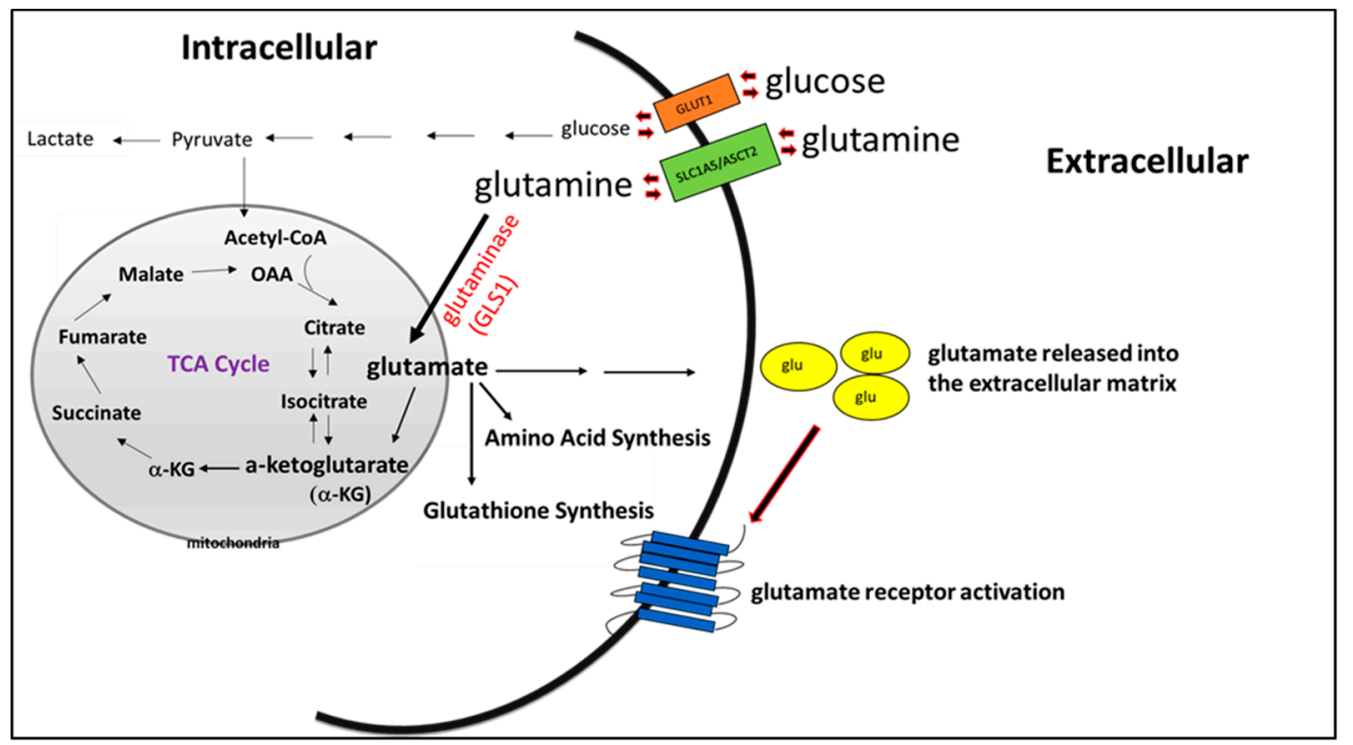

Figure 1. Tumor cells utilize both glutamine and glucose for growth and energy production. Here, we show the several fates of glutamate produced as a result of glutaminolysis.

\section{Cancer Cells Amplify the Release of Extracellular Glutamate}

The role of glutamatergic signaling in tumor biology has been increasingly studied in a variety of malignancies including neuronal tumors, melanoma, breast cancer, prostate cancer, etc. Melanoma cells release excess glutamate into the extracellular environment to warrant constitutive activation of the GRM1 receptor [63]. Moreover, several later studies conducted in different cancer models supported these findings when they detected a more than threefold increase in extracellular glutamate from GRM1 expressing cells compared with controls [64-66]. Similar to the activation of metabotropic glutamate receptors, enhanced glutamate release can also lead to stimulation of ionotropic glutamate receptors (iGluRs). Studies on melanocytes and associated tumors have shown that iGluRs modulate microphthalmia-associated transcription factor (MITF), a factor responsible for melanocyte lineage commitment, and treatment with AMPA receptor antagonists reduces MITF levels, reduces migration, and induces apoptosis [67]. In glioblastoma, calcium entry caused by glutamate-mediated activation of the AMPA receptor increases phosphorylation of cell proliferation and survival pathways [68]. AMPA receptor activation contributes to the lower mitogenic threshold required for oncogene induced signaling and transformation in early pancreatic cancer [69].

Briggs et al. proposed that large amounts of extracellular glutamate, secreted by triple-negative breast cancers, has the potential to inhibit cystine uptake by the cystine-glutamate antiporter $(\mathrm{xCT})$ system [70]. This intracellular depletion of cysteine can increase HIF-1 $\alpha$ expression due to the inactivation of the main HIF- $1 \alpha$ prolyl-hydroxylase [70]. HIF- $1 \alpha$ prolyl-hydroxylases are responsible for the degradation of HIF- $1 \alpha$. Others have reported that the molecular basis for the rewiring of anabolic glutamate metabolism in mammalian cells is linked to HIF-1 $\alpha$ activity [22]. HIF-1 $\alpha$ could also be activated by the PI3K/AKT/mTOR signaling pathway [71], which is upregulated in numerous cancers including GRM1-expressing melanoma cells.

It is well known that stem cells of the neural crest give rise to the cells of the central nervous system (CNS), including astrocytes, glia, and neurons [72]. Melanocytes of the skin also arise from the neural crest stem cells. Due to the similar progenitor origin of the CNS cells and melanocytes, Prickett and Samuels proposed that they may share similar signaling pathways important for homeostasis, proliferation, growth, and overall survival [73]. Glioma, a cancer arising from glia cells in the brain, uses glutamate as an autocrine or paracrine signal to promote cellular migration and invasion [74]. Results from a recent study by Pei et al. indicate that glutamatergic signaling may provide positive feedback through metabolic reprogramming and genetic switching to accelerate glioma duplication 
and progression [75]. Glioma cells release excess glutamate through the $\mathrm{xCT}$ antiporter, which causes the excitotoxic death of neurons and permits tumor-cell expansion [76,77]. That evidence that glutamate-secreting glioma cells exhibit a distinct growth advantage is also noteworthy [78]. It was previously reported that the brain is a preferred site for a secondary melanoma tumor to arise once it becomes metastatic [79]. Therefore, it is interesting to note that when this occurs, excess glutamate released by melanoma cells may further promote tumor growth in a similar fashion to glioma [63]. One of the possible ways for these cells to obtain enough glutamate for subsequent release is by elevating the consumption of glutamine into cells followed by conversion to glutamate via GLS. In addition, enhanced glutamate release has been observed in melanoma as well as breast cancer and prostate cancer cell lines, further supporting the importance of glutamatergic signaling in several malignant phenotype [30].

\section{Can Glutamate Be Used as a Prognostic Biomarker?}

The identification of a reliable predictive clinical biomarker is crucial for precision medicine. Predictive biomarkers are biological molecules detected in most patients and are frequently correlated with treatment responses [80]. Personalized/precision medicine is the future for human disease treatments, and it is essential to identify clinically relevant biomarkers, which can be easily applied in the clinic. Most pre-clinical cancer studies only assess for the efficacy of drug(s) on tumor progression, but it is crucial to also identify predictive biomarkers for treatment responses. Identification of these biomarkers will give clinicians opportunities to make suitable and rational decisions in therapeutic options.

A prognostic tool that has recently been developed measures glutamine addiction in patients [46]. First, a patient is injected with radioactive ${ }^{18} \mathrm{~F}$-labeled $2 \mathrm{~S}, 4 \mathrm{R}$ stereoisomer of 4 -fluoroglutamine $\left({ }^{18} \mathrm{~F}\right.$-glutamine), followed by a position emission tomography/computed tomography $\left({ }^{18} \mathrm{~F}\right.$-glutamine-PET/CT) scans, in contrast to the conventional ${ }^{18} \mathrm{~F}$-glucose (FDG-PET/CT) scan, which measures the Warburg effect [46,81,82]. ${ }^{18} \mathrm{~F}$-glutamine-PET/CT scans are useful in clinics to stage cancer, assess treatment responses, and predict the prognosis of the disease [82]. The development of this tool was only possible due to the understanding that cancer cells exhibit increased glutamine uptake via the SLC1A5 transporter [82]. Furthermore, ${ }^{18} \mathrm{~F}$-glutamine-PET/CT scans have been proposed as a possible tool to monitor the efficacy of glutamine-targeted therapies [46].

Sufficient levels of amino acids in systemic circulation are necessary to satisfy the bioenergetic needs of tumor cells in addition to providing intermediates for macromolecular synthesis [12]. Specifically, amino acids, such as glutamine, glutamate, aspartic acid, and serine are crucial for DNA synthesis, angiogenesis, and protein content amplification [83]. During the process of transformation, the increase in demand for these amino acids leads to increased consumption and subsequent lower bioavailability in cancer patients [84]. In African American and Caucasian American patients with prostate cancer, serum glutamate levels directly correlated with their Gleason score [85]. Likewise, plasma levels of glutamate are increased in colorectal carcinoma patients and in patients who have acquired immunodeficiency syndrome (AIDS) [86]. Other studies by Vanhone et al. and Rodriguez-Tomas et al. elucidate a clinical application to utilize systemic glutamate bioavailability, where they use blood plasma glutamate concentration for the diagnosis of lung cancer with higher specificity $[87,88]$. Interestingly, while investigating whether glutaminases function as prognostic biomarkers in human cancers, Saha et al. revealed that GLS and GLS2 expression can differentially modulate the clinical outcomes depending on the type of cancer [89]. Similar to how patients who carried the mutated BRAF genotype were found to display improved response to vemurafenib therapy $[80,90]$, certain levels of glutamate in the blood could also provide insights into the potential responsiveness of these patients to glutamatergic inhibitors. Metabolic and signaling activities of these biomarkers could pave the way for better prognostic tools and potential therapeutic interventions. 


\section{Glutaminase and Its Inhibition}

GLS is the most well-studied and also the rate-limiting enzyme in the glutaminolysis pathway. Overexpression of GLS allows for increased glutamine metabolism, thereby providing a means for the tumor cells to replenish the citric acid cycle and produce molecules required for anabolic growth. This fundamental insight afforded from basic research, which has provided to the understanding of the glutaminolysis pathway, has allowed for the development of various GLS inhibitors, such as Bis-2-(5-phenylacetamido-1,2,4-thiadazol-2yl) ethyl sulfide (BPTES), CB-839, and compound 968. These have been shown to allosterically inhibit GLS [46,91]. BPTES is specific for the kidney-type glutaminase isoform [92]. The mechanism of action of BPTES occurs by the compound binding to the dimer interface of GLS, thereby inhibiting the tetramerization of GLS, subsequently leading to its inactivation $[46,91]$. BPTES has also been shown to suppress cancer-cell growth in vitro and in vivo [91]. Even though BPTES is a potent inhibitor of GLS, the pharmacokinetic analysis of this compound has revealed that it has poor solubility and bioavailability, thus limiting its potential for clinical use. This led to the development of CB-839 (Telaglenastat ${ }^{\circledR}$ ) by Calithera Biosciences [45]. CB-839, first reported by Gross et al., is a selective, noncompetitive, and potent inhibitor for GLS that has displayed antiproliferative efficacy in many cancers, including melanoma, breast cancer, leukemia/lymphoma, and kidney cancer [93-95]. The recent crystal structure analysis showed that the terminal electron-withdrawing trifluoromethoxy not only increases the integral lipophilicity but also improves the electronegativity of the pyridazinyl nitrogen atoms resulting in strengthened hydrogen bond interaction [96]. In particular, CB-839 is the only small molecule inhibitor of GLS that is being evaluated in clinical settings, currently in phase 1 and 2 clinical trials [97]. Additionally, another member of the GLS allosteric inhibitor family is compound 968. Compound 968 was shown to block oncogenic transformation of fibroblasts, while also displaying antiproliferative effects on cancer cells without affecting their normal counterparts [54]. The mechanism of action of compound 968 is through the binding of it to the monomeric interface of GLS, in comparison with BPTES and CB-839, which bind at the dimer interface [91]. CB-839 and BPTES are known to exclusively inhibit both products of the GLS1 gene, GAC and KGA. However, the pan-glutaminase inhibitor compound 968 targets protein forms of both GLS1 and GLS2 (LGA) and has recently been utilized to suppress luminal-type breast cancer growth by inhibiting the previously underappreciated LGA [98]. In ovarian cancer cells, GLS inhibition enhances the effectiveness of chemotherapy [59] and also improves the efficacy of other targeted therapies [60,61], suggesting the critical role of targeting GLS in an attempt to improve overall patient response. Moreover, the accumulation of glutamine, as a result of GLS inhibition, has been shown to induce divergent metabolic programs to overcome tumor immune evasion [99]. This has been linked to enhanced anti-tumor activity of PD-1 and PD-L1 antibodies by overcoming the blockade of T cell activation [100]. Taken together, GLS inhibitors have shown great pre-clinical promise across cancers; however, resistance is a major hurdle of monotherapy regimes [97].

\section{Resistance to Glutaminase Inhibition}

As a monotherapy, GLS inhibition can be overcome by tumors cells through compensatory mechanisms, specifically against glutamate deprivation through different permutations of asparagine synthetase, a glutamate/cystine antiporter (xCT), or pyruvate carboxylases [101-103]. To overcome GLS inhibition, tumor cells have been shown to upregulate asparagine synthetase, leading to an increase in asparagine concentrations which regulates the uptake of certain amino acids, mammalian target of rapamycin complex 1 (mTORC1) activation, as well as protein and nucleotide synthesis [103]. Additionally, breast cancer cells were shown to be viable even under glucose deprivation, in conjunction with a dysfunctional $\times C T$ antiporter results in the sustenance of mitochondrial respiration [101]. It is possible that $\mathrm{xCT}$ expression is downregulated in CB-839-resistant cells to demote any further glutamate export. The third mechanism of resistance is the upregulation of pyruvate carboxylase [46,102]. Pyruvate carboxylase functions in the conversion of pyruvate into oxaloacetate [46,102]. In relation to glutamate-deprived cells, it can replenish the citric acid cycle and is upregulated in CB-839-resistant 
cancer cells [46,102]. In fact, Parlati and colleagues have suggested that pyruvate carboxylase expression strongly correlates with resistance to CB-839, and that it can rescue cells from GLS inhibition by supporting anapleurotic utilization of glucose [104]. Additionally, it is possible that the environment and metabolic milieu accompanying the tumor is responsible for the apparent resistance to glutaminase inhibition $[105,106]$. Looking towards the future, it might be beneficial for patients to be treated with a combinatorial drug regime that targets two or more proteins within the glutaminolysis pathway. Taking these resistant mechanisms into consideration accentuates the importance of developing a multifaceted approach towards targeting cancer-cell metabolism.

\section{Regulation of Glutaminase}

The regulation of GLS in cancer remains to be fully elucidated. Several studies have proposed different mechanisms by which GLS is regulated. Figure 2 provides a summary of how GLS is potentially regulated in GRM1+ melanoma cells. Gao et al. unfolded the indirect link between c-Myc, a well-known oncogenic transcription factor, and glutamine metabolism. c-Myc has been implicated in both activation and repression of numerous cellular functions, especially metabolism. Elevated levels of c-Myc protein transcriptionally suppress two microRNAs, miR-23a, and miR-23b, which target GLS mRNA. As a result, upregulated expression of mitochondrial GLS induces increasing amounts of glutamate and glutamate-derived metabolites into the TCA cycle to sustain neoplastic progression [62]. Liu and colleagues provided evidences on the correlation between c-Myc overexpression and the mammalian target of rapamycin (mTOR) signaling pathway, which is a critical intracellular regulator of the cell cycle. In $80 \%$ of human cancers, mTOR is abnormally activated and, thus, overstimulates many routes that the transformed cells use to synthesize proteins, lipids, and nucleotides [107]. mTOR serves as the catalytic subunits of two multi-protein complexes: mTOR complex 1 (mTORC1) and complex 2 (mTORC2). mTORC1 has been extensively studied regarding cancer-cell metabolism and has been noted as a major signaling component in regulating anabolic processes necessary for cellular growth. There is also evidence that mTORC1 mediates aerobic glycolysis via hypoxia inducible factor 1 alpha (HIF-1 $\alpha$ ), a transcription factor that functions in initiating angiogenesis and regulating cellular metabolism to overcome hypoxia [108]. The combined features of mTOR signaling have been an active topic of discussion in cancer research and one that our group has been currently investigating. Liu et al. proposed the requirement of an intact mTORC1 axis in c-Myc-driven hepatocarcinogenesis as a possible target for treatment [109]. Rapamycin, a specific inhibitor of mTORC1 activity, is useful in the treatment of certain cancers. However, studies have hypothesized that prolonged rapamycin treatment can considerably reduce levels of mTORC2 [110]. To circumvent this, everolimus was developed. Compared with the parent compound rapamycin, everolimus is more selective for the mTORC1 protein complex, with no impact on the mTORC2 complex [111]. Both rapamycin and everolimus have displayed inhibitory effects on the growth, proliferation, and survival of tumors including melanoma, with minimal toxicity [112]. AKT is a protein kinase downstream of mTORC2 and is controlled via negative feedback regulation from mTORC1. With increased inhibition of mTORC1, there may be hyper-activation of AKT, which can lead to longer cell survival in some cell types. Interestingly, it has been found that the mTORC1/c-Myc axis also regulates GLS expression in pancreatic cancer [113].

Numerous reports have uncovered alternate mechanisms underlying GLS-mediated pathogenesis. Rathore et al. discovered that NF- $\mathrm{KB}$, which is initially defined as a nuclear factor that binds to the $\mathrm{B}$ site of the immunoglobulin $\mathrm{k}$ light chain gene enhancer in B lymphocytes, exhibited similar mechanisms to switch glutamine from a non-essential amino acid to a major energy source [114]. In a human T-lymphocytic cell line, Jurkat, the p65 subunit of NF-kB binds to miR-23a and recruits the histone deacetylase (HDAC) to suppress downstream gene expression, which results in enhanced glutamine consumption [114]. Zhao et al. found that interferon- $\alpha$ (IFN- $\alpha$ ) induced phosphorylation of Signal Transducer and Activator of Transcription 1 (STAT1), which then binds to a GLS promotor resulting in enhanced GLS1 transcription [115]. Lukey et al. unveiled a vital role of the transcription factor c-Jun in metabolic reprogramming. As the product of oncogene JUN, c-Jun directly binds to the GLS promoter 
which increases gene expression in breast cancer cells [116]. Uncovering unique complex networks of GLS regulation that are specific to each cancer type introduces potential for new targeted therapeutics via a "bench to bedside" approach [117].

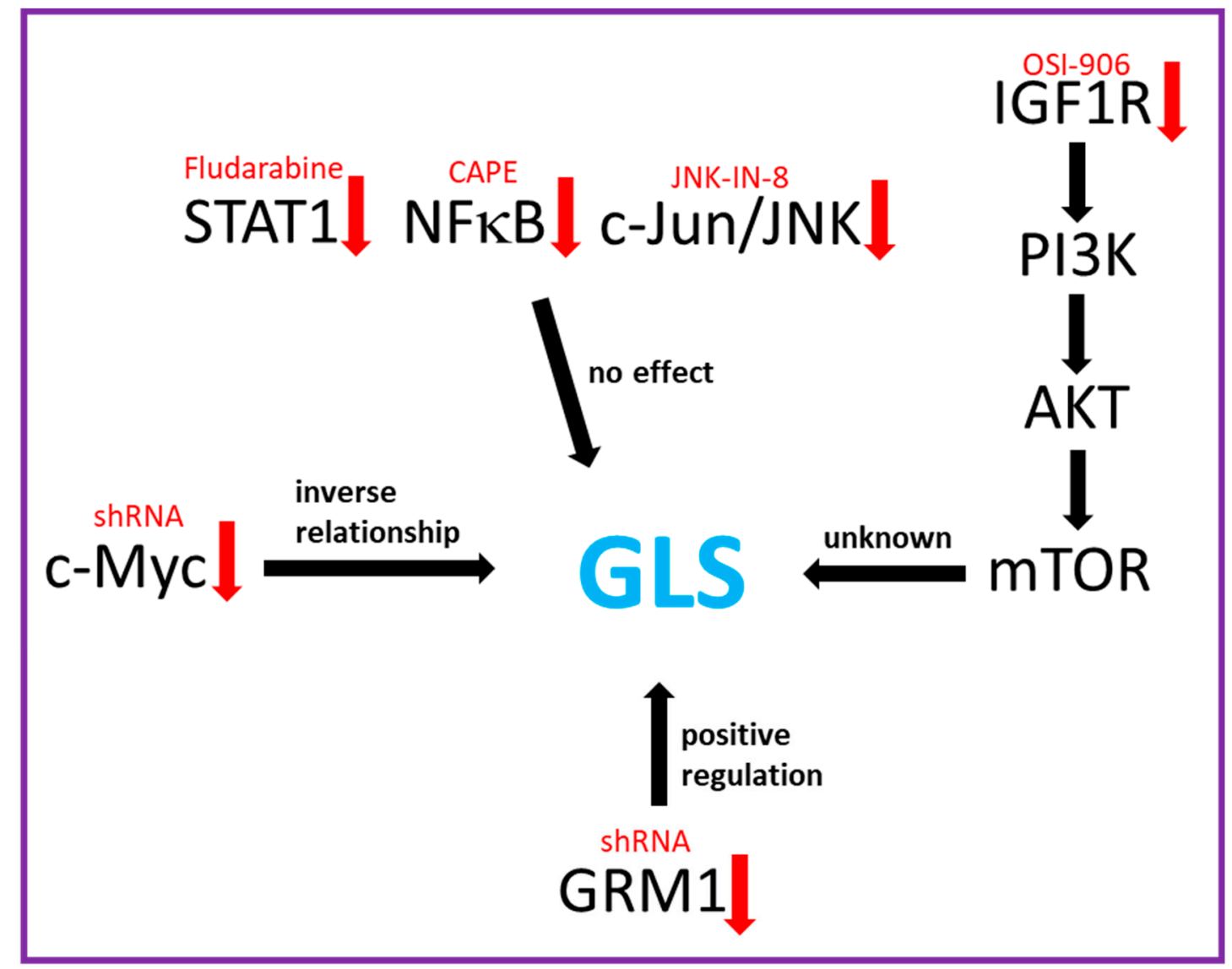

Figure 2. A summary of the proposed pathways/proteins responsible for the regulation of GLS in $\mathrm{GRM}^{+}$melanoma. Red-colored arrows indicate inhibition and black-colored arrows indicate regulation. Red font indicates the mode of inhibition.

\section{Questions for the Future}

The high metabolic demand of cancer results in increased production of mitochondrial reactive oxygen species. To combat this, tumors increase antioxidant production via hyperactivation of the nuclear factor erythroid 2-related factor 2 (NRF2) pathway. NRF2 is the master regulator of a cell's endogenous antioxidant response. Kelch-like ECH-associated protein 1 (Keap1) has been shown to interact with and directly promote proteasomal degradation of NRF2 by cooperating with Cul3, an important component of the E3 ubiquitin ligase complex [118]. Keap1-mutant lung cancer cells have been shown to demonstrate increased sensitivity to GLS inhibition and glutamine deprivation [119]. This sensitivity to GLS inhibition is the result of Keap1-mutated cells being overly dependent on glutaminolysis through proper functioning of xCT transporter [120]. Pharmacologic modulation of the NFR2/GSH pathway paired with subsequent alterations in the expression of $\mathrm{xCT}$ downstream could serve as a predictor of cellular response to resistance and/or sensitivity to certain drugs [121,122]. Moreover, high expression levels of genes related to GSH synthesis, such as glutamate cysteine ligase (GCL) have been shown to promote resistance to anti-cancer treatments [123]. These findings could provide additional insight into the involvement of glutamate utilization. A better understanding of how the NRF2/Keap1 axis functions at the molecular level and how it connects to the glutamatergic pathway in melanoma may help uncover novel regulatory mechanisms of GLS-mediated tumorigenesis. 
Accompanied by the onset of the post-genome era, scientists are now beginning to divert their attention from conventional "one-size-fits-all" therapy to personalized medicine. As the first one to discover that ectopic expression of GRM1 is the driving basis for melanoma development, our group has been actively investigating glutamatergic signaling inhibitors to treat melanoma in experimental models and patients with limited success. Out future goal is to combine inhibitors targeting distinctive but complementary glutamatergic signaling pathways for the treatment of melanoma. A promising candidate as the complementing inhibitor is CB-839. Currently, CB-839 is in clinical trials in combination with other compounds for patients with advanced, metastatic, solid, and hematopoietic tumors [124,125], where glutamine metabolism has been identified as a suitable drug target. Glutaminase inhibition has also been postulated to prime the immune system and improve patients' responsiveness to immune checkpoint therapy [126,127]. We hope to fully identify and unveil the most efficient combination therapy targeting glutamatergic signaling; current therapies may be optimized to prolong the survival of patients.

\section{Conclusions}

Mounting data on aberrant metabolic pathways in cancer etiology suggest deregulated activities of some of the key enzymes constituting specific metabolic pathways could be significant contributors to cancer development and progression. One of the most noticeable reprogramming events in cancer cell metabolisms is the preferential reductive glutamine metabolism even in normoxic conditions. Glutamine, the most abundant circulating amino acid in human plasma, provides considerable nutrient sources including carbons to highly proliferative tumor cells for the production of TCA cycle intermediates, fatty acids, nucleotides and nonessential amino acids. The vital role of glutamine metabolism in cancer cell proliferation suggests glutaminolytic enzymes could be attractive targets for therapy. GLS (glutaminase) converts glutamine to glutamate; elevated GLS levels have been found in tumors and are functionally linked to several oncogenic transcription factors including Myc, NF-kB, c-Jun-induced cell growth in some cancers suggesting the potential of GLS as an important player in therapeutic strategy.

Author Contributions: Conceptualization, R.S. and S.C.; Writing-original draft preparation, R.S.; Writing-review and editing, R.S. and S.C.; Supervision, S.C.; Funding acquisition, S.C. All authors have read and agreed to the published version of the manuscript.

Funding: This work was supported by a grant from New Jersey Health Foundation and Veterans Administration Research award (101BX003742) to S.C. R.S. is thankful for the support of the Bristol-Myers Squibb Graduate Research Fellowship. S.C. and R.S. are grateful for the support of the NIEHS T32 training grant in Environmental Toxicology (ES007148). S.C. and R.S. also appreciate the support of the New York Society of Cosmetic Chemists.

Conflicts of Interest: The authors declare no conflict of interest.

\section{References}

1. Hanahan, D.; Weinberg, R.A. Hallmarks of cancer: The next generation. Cell 2011, 144, 646-674. [CrossRef] [PubMed]

2. Zheng, J. Energy metabolism of cancer: Glycolysis versus oxidative phosphorylation (Review). Oncol. Lett. 2012, 4, 1151-1157. [CrossRef] [PubMed]

3. Vander Heiden, M.G.; Cantley, L.C.; Thompson, C.B. Understanding the Warburg Effect: The Metabolic Requirements of Cell Proliferation. Science 2009, 324, 1029-1033. [CrossRef] [PubMed]

4. Lunt, S.Y.; Heiden, M.G.V. Aerobic Glycolysis: Meeting the Metabolic Requirements of Cell Proliferation. Anпu. Rev. Cell Dev. Biol. 2011, 27, 441-464. [CrossRef]

5. Warburg, O. On the origin of cancer cells. Science 1956, 123, 309-314. [CrossRef]

6. Warburg, O. On respiratory impairment in cancer cells. Science 1956, 124, 269-270.

7. Courtnay, R.; Ngo, D.C.; Malik, N.; Ververis, K.; Tortorella, S.M.; Karagiannis, T.C. Cancer metabolism and the Warburg effect: The role of HIF-1 and PI3K. Mol. Biol. Rep. 2015, 42, 841-851. [CrossRef]

8. Pfeiffer, T.; Schuster, S.; Bonhoeffer, S. Cooperation and Competition in the Evolution of ATP-Producing Pathways. Science 2001, 292, 504-507. [CrossRef] 
9. Locasale, J.W.; Cantley, L.C. Metabolic flux and the regulation of mammalian cell growth. Cell Metab. 2011, 14, 443-451. [CrossRef]

10. Dang, C.V. Links between metabolism and cancer. Genes Dev. 2012, 26, 877-890. [CrossRef]

11. Altman, B.J.; Stine, Z.E.; Dang, C.V. From Krebs to clinic: Glutamine metabolism to cancer therapy. Nat. Rev. Cancer 2016, 16, 619-634. [CrossRef] [PubMed]

12. DeBerardinis, R.J.; Sayed, N.; Ditsworth, D.; Thompson, C.B. Brick by brick: Metabolism and tumor cell growth. Curr. Opin. Genet. Dev. 2008, 18, 54-61. [CrossRef] [PubMed]

13. Stein, W.H.; Moore, S. The free amino acids of human blood plasma. J. Biol. Chem. 1954, 211, 915-926. [PubMed]

14. Biolo, G.; Fleming, R.Y.; Maggi, S.P.; Wolfe, R.R. Transmembrane transport and intracellular kinetics of amino acids in human skeletal muscle. Am. J. Physiol. 1955, 268 Pt 1, E75-E84. [CrossRef]

15. DeBerardinis, R.J.; Cheng, T. Q's next: The diverse functions of glutamine in metabolism, cell biology and cancer. Oncogene 2010, 29, 313-324. [CrossRef] [PubMed]

16. Michalak, K.P.; Maćkowska-Kędziora, A.; Sobolewski, B.; Wozniak, P. Key Roles of Glutamine Pathways in Reprogramming the Cancer Metabolism. Oxid. Med. Cell. Longev. 2015, 2015, 964321. [CrossRef]

17. Filipp, F.V.; Scott, D.A.; Ronai, Z.A.; Osterman, A.L.; Smith, J.W. Reverse TCA cycle flux through isocitrate dehydrogenases 1 and 2 is required for lipogenesis in hypoxic melanoma cells. Pigment Cell Melanoma Res. 2012, 25, 375-383. [CrossRef]

18. Bertout, J.A.; Patel, S.A.; Simon, M.C. The impact of $\mathrm{O}_{2}$ availability on human cancer. Nat. Rev. Cancer 2008, 8, 967-975. [CrossRef]

19. Thompson, C.B. Rethinking the regulation of cellular metabolism. Cold Spring Harb. Symp. Quant. Biol. 2011, 76, 23-29. [CrossRef]

20. Semenza, G.L. Defining the role of hypoxia-inducible factor 1 in cancer biology and therapeutics. Oncogene 2010, 29, 625-634. [CrossRef]

21. Semenza, G.L. HIF-1: Upstream and downstream of cancer metabolism. Curr. Opin. Genet. Dev. 2010, 20, 51-56. [CrossRef]

22. Metallo, C.M.; Gameiro, P.A.; Bell, E.L.; Mattaini, K.R.; Yang, J.; Hiller, K.; Jewell, C.M.; Johnson, Z.R.; Irvine, D.J.; Guarente, L.; et al. Reductive glutamine metabolism by IDH1 mediates lipogenesis under hypoxia. Nature 2012, 481, 380-384. [CrossRef]

23. Veettil, M.V.; Dutta, D.; Bottero, V.; Bandyopadhyay, C.; Gjyshi, O.; Sharma-Walia, N.; Dutta, S.; Chandran, B. Glutamate secretion and metabotropic glutamate receptor 1 expression during Kaposi's sarcoma-associated herpesvirus infection promotes cell proliferation. PLoS Pathog. 2014, 10, e1004389. [CrossRef] [PubMed]

24. Ikonomidou, C.; Bosch, F.; Miksa, M.; Bittigau, P.; Vöckler, J.; Dikranian, K.; Tenkova, T.I.; Stefovska, V.; Turski, L.; Olney, J.W. Blockade of NMDA receptors and apoptotic neurodegeneration in the developing brain. Science 1999, 283, 70-74. [CrossRef]

25. Liou, G.-Y.; Storz, P. Reactive oxygen species in cancer. Free Radic. Res. 2010, 44, 479-496. [CrossRef] [PubMed]

26. Clancy, K.; Berger, R.; Cox, M.; Bleskan, J.; Walton, K.; Hart, I.; Patterson, D. Localization of the L-glutamine synthetase gene to chromosome 1q23. Genomics 1996, 38, 418-420. [CrossRef]

27. Eagle, H. Nutrition needs of mammalian cells in tissue culture. Science 1955, 122, 501-514. [CrossRef]

28. Eagle, H. Amino acid metabolism in mammalian cell cultures. Science 1959, 130, 432-437. [CrossRef]

29. Häberle, J.; Görg, B.; Rutsch, F.; Schmidt, E.; Toutain, A.; Benoist, J.-F.; Gélot, A.; Suc, A.-L.; Hohne, W.; Schliess, F.; et al. Congenital glutamine deficiency with glutamine synthetase mutations. N. Engl. J. Med. 2005, 353, 1926-1933. [CrossRef]

30. Seidlitz, E.; Sharma, M.K.; Saikali, Z.; Ghert, M.; Singh, G. Cancer cell lines release glutamate into the extracellular environment. Clin. Exp. Metastasis 2009, 26, 781-787. [CrossRef] [PubMed]

31. Wasinger, C.; Hofer, A.; Spadiut, O.; Hohenegger, M. Amino Acid Signature in Human Melanoma Cell Lines from Different Disease Stages. Sci. Rep. 2018, 8, 1-13. [CrossRef]

32. Wen, Y.; Li, J.; Koo, J.; Shin, S.-S.; Lin, Y.; Jeong, B.-S.; Mehnert, J.M.; Chen, S.; Cohen-Sola, K.A.; Goydos, J.S.; et al. Activation of the glutamate receptor GRM1 enhances angiogenic signaling to drive melanoma progression. Cancer Res. 2014, 74, 2499-2509. [CrossRef] [PubMed]

33. Zhou, Y.; Danbolt, N.C. Glutamate as a neurotransmitter in the healthy brain. J. Neural. Transm. 2014, 121, 799-817. [CrossRef] [PubMed] 
34. De Groot, J.; Sontheimer, H. Glutamate and the biology of gliomas. Glia 2011, 59, 1181-1189. [CrossRef] [PubMed]

35. Oberndorfer, S.; Schmal, T.; Lahrmann, H.; Urbanits, S.; Lindner, K.; Grisold, W. The frequency of seizures in patients with primary brain tumors or cerebral metastases. An evaluation from the Ludwig Boltzmann Institute of Neuro-Oncology and the Department of Neurology, Kaiser Franz Josef Hospital, Vienna. Wien Klin Wochenschr 2002, 114, 911-916.

36. Rzeski, W.; Ikonomidou, C.; Turski, L. Glutamate antagonists limit tumor growth. Biochem. Pharmacol. 2002, 64, 1195-1200. [CrossRef]

37. Baenke, F.; Chaneton, B.; Smith, M.; Broek, N.V.D.; Hogan, K.; Tang, H.; Viros, A.; Martin, M.; Galbraith, L.; Girotti, M.R.; et al. Resistance to BRAF inhibitors induces glutamine dependency in melanoma cells. Mol. Oncol. 2016, 10, 73-84. [CrossRef]

38. Hernandez-Davies, J.E.; Tran, T.Q.; Reid, M.A.; Rosales, K.R.; Lowman, X.H.; Pan, M.; Moriceau, G.; Yang, Y.; $\mathrm{Wu}, \mathrm{J} . ;$ Lo, R.S.; et al. Vemurafenib resistance reprograms melanoma cells towards glutamine dependence. J. Transl. Med. 2015, 13, 1-11. [CrossRef]

39. Ratnikov, B.; Jeon, Y.J.; Smith, J.W.; Ronai, Z.A. Right on TARGET: Glutamine metabolism in cancer. Oncoscience 2015, 2, 681-683. [CrossRef]

40. Konermann, S.; Brigham, M.D.; Trevino, A.E.; Joung, J.; Abudayyeh, O.O.; Bárcena, C.; Hsu, P.D.; Habib, N.; Gootenberg, J.S.; Nishimasu, H.; et al. Genome-scale transcriptional activation by an engineered CRISPR-Cas9 complex. Nature 2015, 517, 583-588. [CrossRef]

41. Johannessen, C.M.; Johnson, L.A.; Piccioni, F.; Townes, A.; Frederick, D.T.; Donahue, M.K.; Narayan, R.; Flaherty, K.T.; Wargo, J.A.; Root, D.E.; et al. A melanocyte lineage program confers resistance to MAP kinase pathway inhibition. Nature 2013, 504, 138-142. [CrossRef] [PubMed]

42. Teh, J.; Chen, S. mGlu Receptors and Cancerous Growth. Wiley Interdiscip. Rev. Membr. Transp. Signal. 2012, 1, 211-220. [CrossRef] [PubMed]

43. Wall, B.A.; Yu, L.J.; Khan, A.J.; Haffty, B.; Goydos, J.S.; Chen, S. Riluzole is a radio-sensitizing agent in an in vivo model of brain metastasis derived from GRM1 expressing human melanoma cells. Pigment Cell Melanoma Res. 2015, 28, 105-109. [CrossRef] [PubMed]

44. Van Geldermalsen, M.; Wang, Q.; Nagarajah, R.; Marshall, A.D.; Thoeng, A.; Gao, D.; Ritchie, W.; Feng, Y.; Bailey, C.G.; Deng, N.; et al. ASCT2/SLC1A5 controls glutamine uptake and tumour growth in triple-negative basal-like breast cancer. Oncogene 2016, 35, 3201-3208. [CrossRef]

45. Jin, L.; Alesi, G.N.; Kang, S. Glutaminolysis as a target for cancer therapy. Oncogene 2016, 35, 3619-3625. [CrossRef]

46. Yang, L.; Venneti, S.; Nagrath, D. Glutaminolysis: A Hallmark of Cancer Metabolism. Annu. Rev. Biomed. Eng. 2017, 19, 163-194. [CrossRef]

47. Marie, S.K.N.; Shinjo, S.M.O. Metabolism and Brain Cancer. Clinics 2011, 66 (Suppl. 1), 33-43. [CrossRef]

48. DeBerardinis, R.J.; Mancuso, A.; Daikhin, E.; Nissim, I.; Yudkoff, M.; Wehrli, S.; Thompson, C.B. Beyond aerobic glycolysis: Transformed cells can engage in glutamine metabolism that exceeds the requirement for protein and nucleotide synthesis. Proc. Natl. Acad. Sci. USA 2007, 104, 19345-19350. [CrossRef]

49. Katt, W.P.; Cerione, R.A. Glutaminase regulation in cancer cells: A druggable chain of events. Drug Discov. Today 2014, 19, 450-457. [CrossRef]

50. Christa, L.; Simon, M.-T.; Flinois, J.-P.; Gebhardt, R.; Brechot, C.; Lasserre, C. Overexpression of glutamine synthetase in human primary liver cancer. Gastroenterology 1994, 106, 1312-1320. [CrossRef]

51. Osada, T.; Sakamoto, M.; Nagawa, H.; Yamamoto, J.; Matsuno, Y.; Iwamatsu, A.; Muto, T.; Hirohashi, S. Acquisition of glutamine synthetase expression in human hepatocarcinogenesis. Cancer 1999, 85, 819-831. [CrossRef]

52. Sappington, D.R.; Siegel, E.R.; Hiatt, G.; Desai, A.; Penney, R.B.; Jamshidi-Parsian, A.; Griffin, R.J.; Boysen, G. Glutamine drives glutathione synthesis and contributes to radiation sensitivity of A549 and H460 lung cancer cell lines. Biochim. Biophys. Acta 2016, 1860, 836-843. [CrossRef] [PubMed]

53. Katt, W.P.; Lukey, M.J.; Cerione, R.A. A tale of two glutaminases: Homologous enzymes with distinct roles in tumorigenesis. Future Med. Chem. 2017, 9, 223-243. [CrossRef]

54. Wang, J.B.; Erickson, J.W.; Fuji, R.; Ramachandran, S.; Gao, P.; Dinavahi, R.; Wilson, K.F.; Ambrosio, A.L.B.; Dias, S.M.G.; Dang, C.V.; et al. Targeting mitochondrial glutaminase activity inhibits oncogenic transformation. Cancer Cell 2010, 18, 207-219. [CrossRef] 
55. Heuvel, A.P.J.V.D.; Jing, J.; Wooster, R.; Bachman, K.E. Analysis of glutamine dependency in non-small cell lung cancer: GLS1 splice variant GAC is essential for cancer cell growth. Cancer Biol. Ther. 2012, 13, 1185-1194. [CrossRef]

56. Seltzer, M.J.; Bennett, B.D.; Joshi, A.D.; Gao, P.; Thomas, A.G.; Ferraris, D.; Tsukamoto, T.; Rojas, C.J.; Slusher, B.S.; Rabinowitz, J.D.; et al. Inhibition of glutaminase preferentially slows growth of glioma cells with mutant IDH1. Cancer Res. 2010, 70, 8981-8987. [CrossRef]

57. Zhang, J.; Mao, S.Y.; Guo, Y.D.; Wu, Y.; Yao, X.; Huang, Y. Inhibition of GLS suppresses proliferation and promotes apoptosis in prostate cancer. Biosci. Rep. 2019, 39, BSR20181826. [CrossRef]

58. Xiang, Y.; Stine, Z.E.; Xia, J.; Lu, Y.; O'Connor, R.S.; Altman, B.J.; Hsieh, A.L.; Gouw, A.M.; Thomas, A.G.; Gao, P.; et al. Targeted inhibition of tumor-specific glutaminase diminishes cell-autonomous tumorigenesis. J. Clin. Investig. 2015, 125, 2293-2306. [CrossRef]

59. Masamha, C.P.; LaFontaine, P. Molecular targeting of glutaminase sensitizes ovarian cancer cells to chemotherapy. J. Cell. Biochem. 2018, 119, 6136-6145. [CrossRef] [PubMed]

60. Momcilovic, M.; Bailey, S.T.; Lee, J.T.; Fishbein, M.C.; Magyar, C.; Braas, D.; Graeber, T.G.; Jackson, N.J.; Czernin, J.; Emberley, E.; et al. Targeted inhibition of EGFR and glutaminase induces metabolic crisis in EGFR mutant lung cancer. Cell Rep. 2017, 18, 601-610. [CrossRef]

61. Xie, C.; Jin, J.; Bao, X.; Zhan, W.-H.; Han, T.-Y.; Gan, M.; Zhang, C.; Wang, J.-B. Inhibition of mitochondrial glutaminase activity reverses acquired erlotinib resistance in non-small cell lung cancer. Oncotarget 2016, 7, 610-621. [CrossRef]

62. Gao, P.; Tchernyshyov, I.; Chang, T.-C.; Lee, Y.-S.; Kita, K.; Ochi, T.; Zeller, K.I.; De Marzo, A.M.; Van Eyk, J.E.; Mendell, J.T.; et al. c-Myc suppression of miR-23a/b enhances mitochondrial glutaminase expression and glutamine metabolism. Nature 2009, 458, 762-766. [CrossRef] [PubMed]

63. Namkoong, J.; Shin, S.-S.; Lee, H.J.; Marín, Y.E.; Wall, B.A.; Goydos, J.S.; Chen, S. Metabotropic glutamate receptor 1 and glutamate signaling in human melanoma. Cancer Res. 2007, 67, 2298-2305. [CrossRef]

64. Shin, S.-S.; Namkoong, J.; Wall, B.A.; Gleason, R.; Lee, H.J.; Chen, S. Oncogenic activities of metabotropic glutamate receptor 1 (Grm1) in melanocyte transformation. Pigment Cell Melanoma Res. 2008, 21, 368-378. [CrossRef] [PubMed]

65. Martino, J.J.; Wall, B.A.; Mastrantoni, E.; Wilimczyk, B.J.; La Cava, S.N.; Degenhardt, K.; White, E.; Chen, S. Metabotropic Glutamate Receptor 1 (Grm1) is an Oncogene in Epithelial Cells. Oncogene 2013, 32, 4366-4376. [CrossRef] [PubMed]

66. Teh, J.L.F.; Shah, R.; La Cava, S.; Dolfi, S.C.; Mehta, M.S.; Kongara, S.; Price, S.; Ganesan, S.; Reuhl, K.R.; Hirshfield, K.M.; et al. Metabotropic glutamate receptor 1 disrupts mammary acinar architecture and initiates malignant transformation of mammary epithelial cells. Breast Cancer Res. Treat. 2015, 151, 57-73. [CrossRef]

67. Ishiuchi, S.; Tsuzuki, K.; Yoshida, Y.; Yamada, N.; Hagimura, N.; Okado, H.; Miwa, A.; Kurihara, H.; Nakazato, Y.; Tamura, M.; et al. Blockage of $\mathrm{Ca}(2+)$-permeable AMPA receptors suppresses migration and induces apoptosis in human glioblastoma cells. Nat. Med. 2002, 8, 971-978. [CrossRef]

68. Ishiuchi, S.; Yoshida, Y.; Sugawara, K.; Aihara, M.; Ohtani, T.; Watanabe, T.; Saito, N.; Tsuzuki, K.; Okado, H.; Miwa, A.; et al. $\mathrm{Ca}^{2+}$-permeable AMPA receptors regulate growth of human glioblastoma via Akt activation. J. Neurosci. 2007, 27, 7987-8001. [CrossRef]

69. Herner, A.; Sauliunaite, D.; De Oliveira, T.; Abiatari, I.; Kleeff, J.; Michalski, C.W.; Erkan, M.; Kong, B.; Esposito, I.; Friess, H. Glutamate increases pancreatic cancer cell invasion and migration via AMPA receptor activation and Kras-MAPK signaling. Int. J. Cancer 2011, 129, 2349-2359. [CrossRef]

70. Briggs, K.J.; Koivunen, P.; Cao, S.; Backus, K.M.; Olenchock, B.A.; Patel, H.; Zhang, Q.; Signoretti, S.; Gerfen, G.J.; Richardson, A.L.; et al. Paracrine Induction of HIF by Glutamate in Breast Cancer: EgIN1 Senses Cysteine. Cell 2016, 166, 126-139. [CrossRef]

71. Dancey, J. mTOR signaling and drug development in cancer. Nat. Rev. Clin. Oncol. 2010, 7, $209-219$. [CrossRef] [PubMed]

72. Sommer, L. Generation of melanocytes from neural crest cells. Pigment Cell Melanoma Res. 2011, 24, 411-421. [CrossRef]

73. Prickett, T.D.; Samuels, Y. Molecular pathways: Dysregulated glutamatergic signaling pathways in cancer. Clin. Cancer Res. 2012, 18, 4240-4246. [CrossRef] [PubMed]

74. Lyons, S.; Chung, W.J.; Weaver, A.K.; Ogunrinu, T.; Sontheimer, H. Autocrine glutamate signaling promotes glioma cell invasion. Cancer Res. 2007, 67, 9463-9471. [CrossRef] [PubMed] 
75. Pei, Z.; Lee, K.-C.; Khan, A.; Erisnor, G.; Wang, H.-Y. Pathway analysis of glutamate-mediated, calcium-related signaling in glioma progression. Biochem. Pharmacol. 2020, 176, 113814. [CrossRef] [PubMed]

76. Sontheimer, H. A role for glutamate in growth and invasion of primary brain tumors. J. Neurochem. 2008, 105, 287-295. [CrossRef] [PubMed]

77. Ye, Z.C.; Rothstein, J.D.; Sontheimer, H. Compromised glutamate transport in human glioma cells: Reduction-mislocalization of sodium-dependent glutamate transporters and enhanced activity of cystine-glutamate exchange. J. Neurosci. 1999, 19, 10767-10777. [CrossRef]

78. Takano, T.; Lin, J.H.-C.; Arcuino, G.; Gao, Q.; Yang, J.; Nedergaard, M. Glutamate release promotes growth of malignant gliomas. Nat. Med. 2001, 7, 1010-1015. [CrossRef]

79. Xie, T.-X.; Huang, F.-J.; Aldape, K.D.; Kang, S.-H.; Liu, M.; Gershenwald, J.E.; Xie, K.; Sawaya, R.; Huang, S. Activation of stat3 in human melanoma promotes brain metastasis. Cancer Res. 2006, 66, 3188-3196. [CrossRef]

80. Group, F.-N.B.W. Understanding Prognostic versus Predictive Biomarkers; Adminstration, F.A.D., Ed.; National Institutes of Health Silver Spring: Bethesda, MD, USA, 2016.

81. Perng, P.; Marcus, C.; Subramaniam, R.M. 18F-FDG PET/CT and Melanoma: Staging, Immune Modulation and Mutation-Targeted Therapy Assessment, and Prognosis. Am. J. Roentgenol. 2015, 205, 259-270. [CrossRef]

82. Zhu, L.; Ploessl, K.; Zhou, R.; Mankoff, D.; Kung, H.F. Metabolic Imaging of Glutamine in Cancer. J. Nucl. Med. Off. Publ. Soc. Nucl. Med. 2017, 58, 533-537. [CrossRef] [PubMed]

83. Huang, J.; Plass, C.; Gerhauser, C. Cancer chemoprevention by targeting the epigenome. Curr. Drug Targets 2011, 12, 1925-1956. [CrossRef] [PubMed]

84. Proenza, A.M.; Oliver, J.; Palou, A.; Roca, P. Breast and lung cancer are associated with a decrease in blood cell amino acid content. J. Nutr. Biochem. 2003, 14, 133-138. [CrossRef]

85. Koochekpour, S.; Majumdar, S.; Azabdaftari, G.; Attwood, K.; Scioneaux, R.; Subramani, D.; Manhardt, C.; Lorusso, G.D.; Willard, S.S.; Thompson, H.; et al. Serum glutamate levels correlate with Gleason score and glutamate blockade decreases proliferation, migration, and invasion and induces apoptosis in prostate cancer cells. Clin. Cancer Res. 2012, 18, 5888-5901. [CrossRef] [PubMed]

86. Dröge, W.; Eck, H.-P.; Betzler, M.; Her, H.N. Elevated plasma glutamate levels in colorectal carcinoma patients and in patients with acquired immunodeficiency syndrome (AIDS). Immunobiology 1987, 174, 473-479. [CrossRef]

87. Vanhove, K.; Giesen, P.; Owokotomo, O.E.; Mesotten, L.; Louis, E.; Shkedy, Z.; Thomeer, M.; Adriaensens, P. The plasma glutamate concentration as a complementary tool to differentiate benign PET-positive lung lesions from lung cancer. BMC Cancer 2018, 18, 868. [CrossRef]

88. Rodríguez-Tomàs, E.; Arguís, M.; Arenas, M.; Fernández-Arroyo, S.; Murcia, M.; Sabater, S.; Torres, L.; Baiges-Gayà, G.; Hernández-Aguilera, A.; Camps, J.; et al. Alterations in plasma concentrations of energy-balance-related metabolites in patients with lung, or head \& neck, cancers: Effects of radiotherapy. J. Proteom. 2020, 213, 103605.

89. Saha, S.K.; Islam, S.M.R.; Abdullah-Al-Wadud, M.; Ali, F.; Park, K.S.; Islam, S. Multiomics Analysis Reveals that GLS and GLS2 Differentially Modulate the Clinical Outcomes of Cancer. J. Clin. Med. 2019, 8, 355. [CrossRef]

90. Cheng, L.; Lopez-Beltran, A.; Massari, F.; MacLennan, G.T.; Montironi, R. Molecular testing for BRAF mutations to inform melanoma treatment decisions: A move toward precision medicine. Mod. Pathol. 2018, 31, 24-38. [CrossRef]

91. Choi, Y.-K.; Park, K.-G. Targeting Glutamine Metabolism for Cancer Treatment. Biomol. Ther. 2018, 26, 19-28. [CrossRef]

92. Robinson, M.M.; McBryant, S.J.; Tsukamoto, T.; Rojas, C.; Ferraris, D.; Hamilton, S.K.; Hansen, J.C.; Curthoys, N.P. Novel mechanism of inhibition of rat kidney-type glutaminase by bis-2-(5-phenylacetamido-1,2,4-thiadiazol-2-yl)ethyl sulfide (BPTES). Biochem. J. 2007, 406, 407-414. [CrossRef]

93. Gross, M.I.; Demo, S.D.; Dennison, J.B.; Chen, L.; Chernov-Rogan, T.; Goyal, B.; Janes, J.R.; Laidig, G.J.; Lewis, E.R.; Li, J.; et al. Antitumor Activity of the Glutaminase Inhibitor CB-839 in Triple-Negative Breast Cancer. Mol. Cancer Ther. 2014, 13, 890-901. [CrossRef] 
94. Abu Aboud, O.; Habib, S.L.; Trott, J.; Stewart, B.; Liang, S.; Chaudhari, A.J.; Sutcliffe, J.; Weiss, R.H. Glutamine Addiction in Kidney Cancer Suppresses Oxidative Stress and can be Exploited for Real-Time Imaging. Cancer Res. 2017, 77, 6746-6758. [CrossRef] [PubMed]

95. Parlati, F.; Bromley-Dulfano, S.; Demo, S.; Janes, J.; Gross, M.; Lewis, E.; MacKinnon, A.; Rodriguez, M.; Yang, J.; Zhao, F.; et al. Antitumor Activity of the Glutaminase Inhibitor CB-839 in Hematological Malignances. Blood 2013, 122, 4226. [CrossRef]

96. Ramachandran, S.; Pan, C.Q.; Zimmermann, S.C.; Duvall, B.; Tsukamoto, T.; Low, B.C.; Sivaraman, J. Structural basis for exploring the allosteric inhibition of human kidney type glutaminase. Oncotarget 2016, 7 , 57943-57954. [CrossRef] [PubMed]

97. Song, M.; Kim, S.-H.; Im, C.Y.; Hwang, H.-J. Recent Development of Small Molecule Glutaminase Inhibitors. Curr. Top. Med. Chem. 2018, 18, 432-443. [CrossRef] [PubMed]

98. Lukey, M.J.; Cluntun, A.A.; Katt, W.P.; Lin, M.-C.J.; Druso, J.E.; Ramachandran, S.; Erickson, J.W.; Le, H.H.; Wang, Z.-E.; Blank, B.; et al. Liver-Type Glutaminase GLS2 is a Druggable Metabolic Node in Luminal-Subtype Breast Cancer. Cell Rep. 2019, 29, 76-88.e7. [CrossRef]

99. Leone, R.D.; Zhao, L.; Englert, J.M.; Sun, I.-M.; Oh, M.-H.; Arwood, M.L.; Bettencourt, I.A.; Patel, C.H.; Wen, J.; Tam, A.; et al. Glutamine blockade induces divergent metabolic programs to overcome tumor immune evasion. Science 2019. [CrossRef]

100. Gross, M.; Chen, J.; Englert, J.; Janes, J.; Leone, R.; MacKinnon, A.; Parlati, F.; Rodriquez, M.; Shwonek, P.; Powell, J. Abstract 2329: Glutaminase inhibition with CB-839 enhances anti-tumor activity of PD-1 and PD-L1 antibodies by overcoming a metabolic checkpoint blocking T cell activation. Cancer Res. 2016, 76, 2329.

101. Shin, C.-S.; Mishra, P.; Watrous, J.D.; Carelli, V.; D’Aurelio, M.; Jain, M.; Chan, D.C. The glutamate/cystine xCT antiporter antagonizes glutamine metabolism and reduces nutrient flexibility. Nat. Commun. 2017, 8, 1-11. [CrossRef]

102. MacKinnon, A.; Bennett, M.; Rodriguez, M.; Parlati, F. Biomarkers of Response to the Glutaminase Inhibitor CB-839 in Multiple Myeloma Cells. Blood. 2014, 124, 3429. [CrossRef]

103. Krall, A.S.; Xu, S.; Graeber, T.G.; Braas, D.; Christofk, H.R. Asparagine promotes cancer cell proliferation through use as an amino acid exchange factor. Nat. Commun. 2016, 7, 1-13. [CrossRef] [PubMed]

104. MacKinnon, A.L.; Bennett, M.; Gross, M.; Janes, J.; Li, W.; Rodriquez, M.; Wang, T.; Zhang, W.; Parlati, F. Metabolomic, Proteomic and Genomic Profiling Identifies Biomarakers of Sensitivity to Glutaminase Inhibitor CB-839 in Multiple Myeloma. Blood 2015, 126, 1802. [CrossRef]

105. Davidson, S.M.; Papagiannakopoulos, T.; Olenchock, B.A.; Heyman, J.E.; Keibler, M.A.; Luengo, A.; Bauer, M.R.; Jha, A.K.; O’Brien, J.P.; Pierce, K.A.; et al. Environment Impacts the Metabolic Dependencies of Ras-Driven Non-Small Cell Lung Cancer. Cell Metab. 2016, 23, 517-528. [CrossRef] [PubMed]

106. Sullivan, M.R.; Danai, L.V.; Lewis, C.A.; Chan, S.H.; Gui, D.Y.; Kunchok, T.; Dennstedt, E.A.; Heiden, M.G.V.; Muir, A. Quantification of microenvironmental metabolites in murine cancers reveals determinants of tumor nutrient availability. eLife 2019, 8, e44235. [CrossRef]

107. Menon, S.; Manning, B.D. Common corruption of the mTOR signaling network in human tumors. Oncogene 2008, 27 (Suppl. 2), S43-S51. [CrossRef]

108. Majumder, P.K.; Febbo, P.G.; Bikoff, R.; Berger, R.; Xue, Q.; McMahon, L.M.; Manola, J.; Brugarolas, J.; McDonnell, T.J.; Golub, T.R.; et al. mTOR inhibition reverses Akt-dependent prostate intraepithelial neoplasia through regulation of apoptotic and HIF-1-dependent pathways. Nat. Med. 2004, 10, 594-601. [CrossRef]

109. Liu, P.; Ge, M.; Hu, J.; Li, X.; Che, L.; Sun, K.; Cheng, L.; Huang, Y.; Pilo, M.G.; Cigliano, A.; et al. A functional mammalian target of rapamycin complex 1 signaling is indispensable for c-Myc-driven hepatocarcinogenesis. Hepatology 2017, 66, 167-181. [CrossRef]

110. Sarbassov, S.D.; Ali, S.M.; Sengupta, S.; Sheen, J.-H.; Hsu, P.P.; Bagley, A.F.; Markhard, A.L.; Sabatini, D.M. Prolonged rapamycin treatment inhibits mTORC2 assembly and Akt/PKB. Mol. Cell 2006, 22, 159-168. [CrossRef]

111. Apelo, S.I.A.; Neuman, J.C.; Baar, E.L.; Syed, F.A.; Cummings, N.E.; Brar, H.K.; Pumper, C.P.; Kimple, M.E.; Lamming, D.W. Alternative rapamycin treatment regimens mitigate the impact of rapamycin on glucose homeostasis and the immune system. Aging Cell 2016, 15, 28-38. [CrossRef]

112. Buscà, R.; Bertolotto, C.; Ortonne, J.-P.; Ballotti, R. Inhibition of the phosphatidylinositol 3-kinase/p70(S6)-kinase pathway induces B16 melanoma cell differentiation. J. Biol. Chem. 1996, 271, 31824-31830. [CrossRef] 
113. Csibi, A.; Lee, G.; Yoon, s.-o.; Tong, H.; Ilter, D.; Elia, I.; Fendt, S.-M.; Roberts, T.M.; Blenis, J. The mTORC1/S6K1 pathway regulates glutamine metabolism through the eIF4B-dependent control of c-Myc translation. Curr. Biol. 2014, 24, 2274-2280. [CrossRef]

114. Rathore, M.G.; Saumet, a.; Rossi, j.-f.; de Bettignies, C.; Tempé, D.; Lecellier, C.-H.; Villalba, M. The NF-kappaB member p65 controls glutamine metabolism through miR-23a. Int. J. Biochem. Cell Biol. 2012, 44, 1448-1456. [CrossRef]

115. Zhao, L.; Huang, Y.; Tian, C.; Taylor, L.; Curthoys, N.; Wang, Y.; Vernon, H.; Zheng, J.C. Interferon-alpha regulates glutaminase 1 promoter through STAT1 phosphorylation: Relevance to HIV-1 associated neurocognitive disorders. PLOS ONE 2012, 7, e32995.

116. Lukey, M.J.; Greene, K.S.; Erickson, J.W.; Wilson, K.F.; Cerione, R.A. The oncogenic transcription factor c-Jun regulates glutaminase expression and sensitizes cells to glutaminase-targeted therapy. Nat. Commun. 2016, 7, 1-4. [CrossRef]

117. Verma, M. Personalized medicine and cancer. J. Pers. Med. 2012, 2, 1-14. [CrossRef]

118. McMahon, M.J.; Itoh, K.; Yamamoto, M.; Hayes, J.D. Keap1-dependent proteasomal degradation of transcription factor $\mathrm{Nrf} 2$ contributes to the negative regulation of antioxidant response element-driven gene expression. J. Biol. Chem. 2003, 278, 21592-21600. [CrossRef]

119. Romero, R.; Sayin, V.I.; Davidson, S.M.; Bauer, M.R.; Singh, S.X.; Leboeuf, S.; Karakousi, T.R.; Ellis, D.C.; Bhutkar, A.; Sánchez-Rivera, F.J.; et al. Keap1 loss promotes Kras-driven lung cancer and results in dependence on glutaminolysis. Nat. Med. 2017, 23, 1362-1368. [CrossRef]

120. Sayin, V.I.; Leboeuf, S.; Singh, S.X.; Davidson, S.M.; Biancur, D.; Guzelhan, B.S.; Alvarez, S.W.; Wu, W.L.; Karakousi, T.R.; Zavitsanou, A.M.; et al. Activation of the NRF2 antioxidant program generates an imbalance in central carbon metabolism in cancer. eLife 2017, 6, e28083. [CrossRef]

121. Huang, Y.; Dai, Z.; Barbacioru, C.; Sadee, W. Cystine-glutamate transporter SLC7A11 in cancer chemosensitivity and chemoresistance. Cancer Res. 2005, 65, 7446-7454. [CrossRef]

122. Tang, X.; Fu, X.; Liu, Y.; Yu, D.; Cai, S.J.; Yang, C. Blockade of Glutathione Metabolism in IDH1-Mutated Glioma. Mol. Cancer Ther. 2020, 19, 221-230. [CrossRef] [PubMed]

123. Hiyama, N.; Ando, T.; Maemura, K.; Sakatani, T.; Amano, Y.; Watanabe, K.; Kage, H.; Yatomi, Y.; Nagase, T.; Nakajima, J.; et al. Glutamate-cysteine ligase catalytic subunit is associated with cisplatin resistance in lung adenocarcinoma. Jpn. J. Clin. Oncol. 2018, 48, 303-307. [CrossRef] [PubMed]

124. Meric-Bernstam, F.; Lee, R.J.; Carthon, B.C.; Iliopoulos, O.; Mier, J.W.; Patel, M.R.; Tannir, N.M.; Owonikoko, T.K.; Haas, N.B.; Voss, M.H.; et al. CB-839, a glutaminase inhibitor, in combination with cabozantinib in patients with clear cell and papillary metastatic renal cell cancer (mRCC): Results of a phase I study. J. Clin. Oncol. 2019, 37 (Suppl. 7), 549. [CrossRef]

125. Kalinsky, K.; Harding, J.; DeMichele, A.; Infante, J.; Gogineni, K.; Owonikoko, T.; Isakoff, S.; Iliopoulos, O.; Patel, M.R.; Münster, P.; et al. Abstract PD3-13: Phase 1 study of CB-839, a first-in-class oral inhibitor of glutaminase, in combination with paclitaxel in patients with advanced triple negative breast cancer. Cancer Res. 2018, 78 (Suppl. 4), PD3-13.

126. Keir, M.E.; Butte, M.J.; Freeman, G.J.; Sharpe, A. PD-1 and its ligands in tolerance and immunity. Annu. Rev. Immunol. 2008, 26, 677-704. [CrossRef]

127. Alsaab, H.O.; Sau, S.; Alzhrani, R.; Tatiparti, K.; Bhise, K.; Kashaw, S.K.; Iyer, A.K. PD-1 and PD-L1 Checkpoint Signaling Inhibition for Cancer Immunotherapy: Mechanism, Combinations, and Clinical Outcome. Front. Pharmacol. 2017, 8, 561. [CrossRef]

(C) 2020 by the authors. Licensee MDPI, Basel, Switzerland. This article is an open access article distributed under the terms and conditions of the Creative Commons Attribution (CC BY) license (http://creativecommons.org/licenses/by/4.0/). 